\title{
Multicriteria assessment of selected types of the single-layer exterior walls
}

\author{
Piotr Plebankiewicz ${ }^{1}$, and Agnieszka Leśniak ${ }^{2 *}$ \\ ${ }^{1}$ Cracow University of Technology, Department of Civil Engineering, Warszawska 24, 31-155 \\ Kraków, Poland
}

\begin{abstract}
The choice of technology for the construction of external walls and materials is made at the building design stage. This is one of the key decisions, any change after the beginning of construction is bound to cause serious consequences. It is therefore worth analysing various design solutions beforehand, taking into account the cost, quality, execution time, as well as the partition parameters obtained. The paper presents three variants of the solution for single-layer external walls that can be used in single-family buildings. Costs were calculated and selected technical parameters were listed. The evaluation of the proposed variants was made using the multi-criteria analysis method.
\end{abstract}

\section{Introduction}

Walls are structural elements of buildings to perform the function of load transfer (mainly vertical load components). They constitute a barrier separating the interior of the building from the external space, as well as protect it from the influence of the external environment (external walls), or separate rooms from each other (internal walls) [8]. Static, technical and economic considerations mainly determine the choice of structure and thickness of the walls. From static viewpoint the most important factors are: the method of fixing the wall resulting from the structural layout of the building and the size of the loads acting on it. From the economic and technical point of view, the choice of wall construction is mainly determined by thermal and acoustic insulation.

The properties of the wall are determined primarily by its constituting the materials from which it was made. Their selection depends on the purpose and function of the wall in the building. Depending on the location in the building, the walls can be divided into external and internal ones. Within this categorization, a fundamental difference in the requirements for both types of walls is encountered. External walls should be characterized mostly, by a suitable load-bearing capacity (strength), as well as thermal-humidity and acoustic insulation. It is also important to ensure their required fire resistance, long-term service life and high accumulation and thermal stability. Vital properties also include resistance to the impact of the atmosphere; i.e, frost resistance, biological resistance and corrosion resistance. Further requirements are: low humidity in the air-dry state, the ability to quickly dry out, rather low absorbability and small capillary rise. External walls should

*Corresponding author: alesniak@L3.pk.edu.pl 
trigger a positive effect on the health conditions in the rooms. An important feature is also the aesthetic appearance and the possible low cost of materials and implementation [9]. Nowadays, when choosing building materials, attention is paid not only to the cost of purchase but also to the cost of the building's life cycle $[1,5,10,13]$.

Producers of materials for building walls for years have ensured that single-layer walls are an ideal solution for everyone who values the speed of bricklaying work, as well as the accuracy of works implementation. Due to the lack of additional insulation layers, the duration of construction is much shorter than that of other types of walls. An important advantage is also a lower probability of execution errors, often occurring during the construction of thermal insulation layers in double-layer partitions.

The aim of the paper is to present selected three solutions for single-layer walls used in single-family housing. The proposed variants were compared in terms of the necessary costs of their construction and their selected technical parameters. To evaluate the variants the multi-criteria analysis method was used.

\section{External walls - division and requirements}

Considering the structural function and the type of loads carried, the following walls are differentiated [8, 11]: load-bearing, self-supporting, shielding and partition ones. A division according to the technology of implementation involves [8, 11]: brick, prefabricated and monolithic ones. Due to the technology of constructing vertical brick partitions, they can be divided into $[8,11]$ :

- Three-layer walls which consist of two vertical, parallel layers of the wall. They are connected with each other by anchors and the space that lies between them forms a gap filled, unfilled or partially filled with non-structural material [11]. The arrangement of the layers in the diaphragm wall is beneficial from the perspective of the building physics. The shielding wall can be made of bricks and fittings, it is durable and allows the attachment of heavy decorations, yet it generates additional costs.

- Two-layer walls are partitions in which the wall is a construction element and insulation forms a barrier to the escape of heat from the building. Instead of the shielding layer, the partition has a plaster that protects the insulation from damage. It is the insulation of the partition that determines its thermal efficiency. It prevents the formation of thermal bridges and any additional loss of energy. Due to the external plaster on the mesh, the partition has a low resistance to mechanical loads.

- Single-layer walls are made of only one layer - structural one with plaster on its both sides. This type of walls is mainly characterized by the speed of bricklaying work and the accuracy of execution which is easier to attain. To make single-layer walls, the warmest varieties of hollow clay bricks, expanded clay concrete or aerated concrete are used. The choice of materials for building walls is diverse, and their use brings both advantages and disadvantages.

The increasing awareness of the value of the share of energy necessary for heating and cooling of residential buildings in the overall assessment of energy consumption made the requirements for thermal insulation of external walls consistently heightened. In Poland in accordance with the Regulation of the Minister of Transport, Construction and Maritime Economy of July 5, 2013 from January 1, 2017, amending the regulation on technical conditions which should be met by buildings and their location (Journal of Laws of 2013, item 926), heat transfer coefficient UC (max) for external walls, at the temperature of the heated room $\geq 16^{\circ} \mathrm{C}$, was lowered and amounts to $0.23 \mathrm{~W} / \mathrm{m}^{2} \mathrm{~K}$. What is more, from 2021 this value will be only $0.2 \mathrm{~W} / \mathrm{m}^{2} \mathrm{~K}$. 
In the case of walls, acoustic insulation is also important, which in Poland is defined in the Polish Standard PN-B-02151-3: 2015-10 Building acoustics - Protection against noise in buildings - Part 3: Requirements for sound insulation of partitions in buildings and building elements. RA2 acoustic insulation determined for external walls depends on the type of the wall (with windows / no windows) and on the sound level A in $\mathrm{dB}$ of external noise in the surrounding of the building.

The technical conditions that should be met by the partition in the event of a fire have also been developed. The fire resistance of individual building elements is characterized by two or three criteria whose definitions and the required values can be found in the Notice of the Minister of Infrastructure and Development of July 17, 2015, regarding the technical conditions that should be met by buildings and their location (Journal of Laws 2015, 1422). Section VI Fire safety, Chapter 2. Fire resistance of buildings.

\section{Variantization of solutions for the external walls of single-layer housing buildings}

The choice of variants of the implementation of single-layer external walls is dictated by the choice of such solutions that currently meet the heat transfer coefficient of $0.2 \mathrm{~W} / \mathrm{m} 2 \mathrm{~K}$, required from 2021.

\subsection{Variant I - single-layer wall made of ceramics filled with mineral wool}

Ceramic products are characterized by good compressive strength, frost resistance and fire resistance and their important advantage is the favorable microclimate that such products create in the room [8]. Ceramic materials for building walls include bricks and hollow blocks. Considering the low thermal insulation of ceramic bricks, they are usually avoided in non-insulated single-layer walls. Porous ceramics deserves attention, since due to the process of achieving air-filled micropores with an enlarged surface in the ceramic material and a special drill system and shape, the heat path that penetrates the wall is significantly longer. As a result, the heat conduction coefficient is more than twice smaller than in ceramic hollow blocks [8]. One of the newer solutions on the market is a ceramic hollow block filled with mineral wool Porotherm $44 \mathrm{~T}$ Dryfix [2]. The heat transfer coefficient is $0.17\left[\mathrm{~W} / \mathrm{m}^{2} \mathrm{~K}\right]$. The wool inside is hydrophobic. It also has the ability to pass water vapor, so there is no risk of mold growth in the block. The technology of constructing walls in this system consists in bricking dry ceramic blocks. The producer [2] also offers a thin-layer mortar based on polyurethane, which is completely water-free.

\subsection{Variant II - single-layer wall made of cellular concrete blocks}

Cellular concrete is a building material produced from aerated cement-lime, lime or cement mortar. As a result of the introduction of gas under appropriate pressure into the mixture, homogeneous pores, called cells, are formed [11]. Different methods of producing pores in concrete result in the following types [12]: autoclaved aerated concrete, foamed concrete and foamed-aerated concrete. An important advantage of cellular concrete is the ease of processing and bricklaying, as well as its lightness. In the considered variant, a block of cellular concrete of YTONG ENERGO [14] was adopted, for which the heat transfer coefficient is 0.19 [W/ $\left./ \mathrm{m}^{2} \mathrm{~K}\right]$. In order to maintain high thermal insulation properties of the material on an entire partition, it is extremely important to guarantee a sufficiently high quality of execution. Special mortars should be used in this case [14]. 


\subsection{Variant III - single-layer wall from light expanded clay aggregate concrete blocks with an insulating expanded polystyrene insert}

While adding expanded clay to concrete (mineral aggregate produced as a result of foaming and sintering of clay raw materials in rotary kilns) light expanded clay aggregate (leca) concrete is formed. The leca concrete elements are observed as the most popular products made of lightweight aggregate concretes. Depending on the destination, products of various sizes can be found on the market. For constructing single-layer walls hollow blocks 36.5 and $38 \mathrm{~cm}$ wide are used most often. They are characterized by a heat transfer coefficient $\mathrm{U}$ of about $0.33 \mathrm{~W} / \mathrm{m}^{2} \mathrm{~K}$ [3]. Regarding thermal insulation, blocks filled with expanded polystyrene are a more advantageous solution. In the third variant of the single-layer wall, the HOTBLOK system was proposed - leca concrete blocks with a core in the form of thermal insulation inserts for which the heat transfer coefficient is $0.17\left[\mathrm{~W} / \mathrm{m}^{2} \mathrm{~K}\right]$ [3].

Figure 1 shows selected hollow bricks for the construction of the proposed variants of the single-layer external wall.

a)

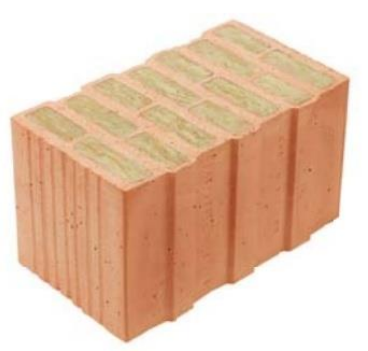

b)

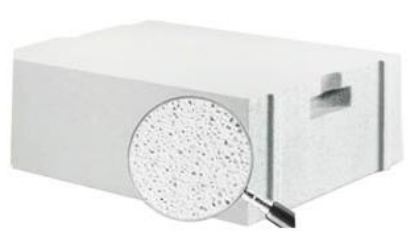

c)

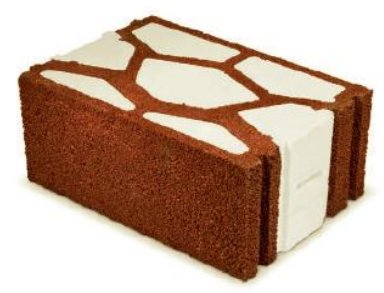

Fig. 1. Example construction materials for laying single-layered external walls: a) Hollow brick Porotherm 44 T Dryfix [2]; b) YTONG ENERGO block 48cm thick [13]; c) HOTBLOK leca concrete block with a polystyrene insert [3].

\section{Costs and selected technical parameters of the proposed single-layer wall variants}

The cost calculation includes $1 \mathrm{~m}^{2}$ of the full partition. The cost of lintels, window openings and plastering was not included. The cost of selected variants were estimated according to catalogues: KNR K-49 (for variant I), KNR K-28 (for variant II) and KNRW 2-02 used by analogy (for variant III). The calculation included only direct costs: labour, material and equipment.

Table 1. The unit price and labour intensity for the selected variants of a single-layer wall.

\begin{tabular}{|l|c|c|}
\hline \multicolumn{1}{|c|}{ Variant } & $\begin{array}{c}\text { Unit price } \\
{\left[\mathbf{P L N} / \mathbf{m}^{2}\right]}\end{array}$ & $\begin{array}{c}\text { Labour } \\
\text { intensity } \\
{\left[\mathbf{w}-\mathbf{h} / \mathbf{m}^{2}\right]}\end{array}$ \\
\hline $\begin{array}{l}\text { Variant I } \\
\text { A wall made of ceramic hollow blocks filled with mineral wool }\end{array}$ & 328.43 & 1.32 \\
\hline $\begin{array}{l}\text { Variant II } \\
\text { Wall made of cellular concrete blocks }\end{array}$ & 182.38 & 1.02 \\
\hline $\begin{array}{l}\text { Variant III } \\
\text { Wall made of leca concrete blocks with an insulating expanded } \\
\text { polystyrene insert }\end{array}$ & 317.28 & 1.97 \\
\hline
\end{tabular}


Financial basis used for calculations include:

- labour cost -14.80 PLN/w-h.

- materials and equipment prices were taken from the market or the price publications.

Costs of purchases of materials are included in the prices of materials. Table 1 presents the calculation results.

Due to the assumptions made, the most expensive solution is manufacturing $1 \mathrm{~m}^{2}$ of a ceramic hollow wall filled with mineral wool. The cheapest is the wall built from a cellular concrete block. The greatest labour intensity (based on the data from catalogues KNR K-49, KNRK-28, KNR 2-02) is involved in building the leca concrete block wall, while the lowest - the cellular concrete block.

Table 2 illustrates the selected technical parameters of the materials used in the variants under consideration.

Table 2. Selected technical parameters for the materials used in the analyzed variants.

\begin{tabular}{|l|c|c|c|}
\hline \multicolumn{1}{|c|}{ Parameter } & $\begin{array}{c}\text { Porotherm 44 T } \\
\text { Dryfix }\end{array}$ & $\begin{array}{c}\text { YTONG } \\
\text { ENERGO }\end{array}$ & HOTBLOK \\
\hline Heat transfer coefficient U $\left[\mathrm{W} / \mathrm{m}^{2} \mathrm{~K}\right]$ & 0.17 & 0.19 & 0.15 \\
\hline Fire classification & REI 90 & REI 240 & REI 120 \\
\hline Sound insulation [dB] & 48 & 42 & 46 \\
\hline Compression endurance [MPa] & 7.5 & 2 & 1.5 \\
\hline Wall thickness [cm] & 44 & 48 & 42 \\
\hline Hollow block mass [kg] & 19 & 20 & $22-23$ \\
\hline
\end{tabular}

Source: analysis based on the producers' data $[2,3,14]$.

Based on the information in the table, in terms of technical parameters, Porotherm $44 \mathrm{~T}$ Dryfix block shows the most favorable values.

\section{A multi-criteria analysis for selected walls variants}

The applications of multi-criteria analysis supporting decision making in the construction industry were presented, e.g. in $[4,6,7]$. The methods of a multi-criteria comparative analysis include a class of algorithms that create a scalar whose numerical value becomes a synthetic evaluation index - the so-called "mathematical methods" [15]. The application of the synthetic evaluation indices requires division of the evaluation criteria into stimulants which are positively correlated with the dependent variable, and negatively correlated destimulants. The most frequently used discrete multi-criteria method is the corrected summation index [16].

In order to provide the comparison and evaluation of the variants, the chosen evaluations of the criteria should be given dimensionless quantities, due to which it is possible to compare not only the quantitative but also the qualitative features. The procedure involves three steps [15]:

1. determining the corrected values of criteria evaluations for individual variants (stimulant, destimulant),

2. determining the coded values of criteria evaluations for individual variants,

3. determining the corrected summation index $J i$ according to formula (1).

$$
J_{i}=\sum_{j=1}^{m}\left(z_{i j} \cdot v_{j}\right)
$$


where:

$J_{i} \quad$ the synthetic evaluation of the $i$-th variant,

$M \quad$ the number of criteria,

$z_{i j} \quad$ the coded measure of the $i$-th variant in relation to $j$-th criterion,

$v_{j} \quad$ the weight of the $j$-th criterion.

To perform the multi-criteria analysis the authors proposed four criteria. The criteria and their values are presented in Table 3.

Table 3. Proposed criteria and their measures (analysis based on the producers' data [2, 3, 14]).

\begin{tabular}{|c|c|c|c|c|c|}
\hline \multirow[b]{3}{*}{ Criterion } & \multirow[b]{3}{*}{$\begin{array}{l}\text { The nature } \\
\text { of the criterion }\end{array}$} & \multirow{3}{*}{$\begin{array}{l}\text { Weight } \\
\text { of the } \\
\text { criterion }\end{array}$} & \multicolumn{3}{|c|}{ Measure of the criterion for the variant } \\
\hline & & & $\mathrm{V}_{1}$ & $\mathbf{V}_{\mathbf{2}}$ & $\mathbf{V}_{3}$ \\
\hline & & & $\begin{array}{c}\text { Ceramics } \\
\text { with } \\
\text { mineral } \\
\text { wool }\end{array}$ & $\begin{array}{l}\text { Cellular } \\
\text { concrete }\end{array}$ & $\begin{array}{l}\text { Leca concrete } \\
\text { with styrofoam } \\
\text { insert }\end{array}$ \\
\hline $\begin{array}{l}\mathrm{K}_{1} \text { coefficient } \mathrm{U} \\
{\left[\mathrm{W} / \mathrm{m}^{2} \mathrm{~K}\right]}\end{array}$ & Destimulant & 0.20 & 0.17 & 0.19 & 0.15 \\
\hline $\begin{array}{l}\mathrm{K}_{2} \text { execution cost } \\
{[\mathrm{zl} / \mathrm{m} 2]}\end{array}$ & Destimulant & 0.60 & 328.43 & 182.38 & 317.28 \\
\hline $\begin{array}{l}\mathrm{K}_{3} \text { labour intensity } \\
{[\mathrm{w}-\mathrm{h}]}\end{array}$ & Destimulant & 0.10 & 1.32 & 1.02 & 1.97 \\
\hline $\begin{array}{l}\mathrm{K}_{4} \text { sound insulation } \\
{[\mathrm{dB}]}\end{array}$ & Stimulant & 0.10 & 48 & 42 & 46 \\
\hline
\end{tabular}

In order to compare the variants, one has to use a method of data coding because it is impossible to equate such specific factors as price and time. Many different methods of data coding can be found in literature $[4,6,7]$. To encode the data, the NeumannMorgenstern method was used to maximize the objectivity of the result. It is a one of the most popular method of data coding used in construction decision problems $[6,15]$. A detailed description of the method can be found in [15]. Coding was made using the formulas (2) i (3):

- for stimulants:

$$
\frac{x_{i j}-x_{i \min }}{x_{j \max }-x_{j \min }}
$$

- for destimulants:

$$
z_{i j}=z_{i j}=\frac{x_{j \max }-x_{i j}}{x_{j \max }-x_{j \min }}
$$

where:

$\begin{array}{ll}x_{j \min } & \text { the minimum value of the } \mathrm{j} \text {-th criterion measure, } \\ x_{j \max } & \text { the maximum value of the } \mathrm{j} \text {-th criterion measure, } \\ x_{i j} & \text { partial measure according to the criterion } \mathrm{K}_{\mathrm{j}} \text { for the variant } \mathrm{W}_{\mathrm{i}} .\end{array}$

Table 4 illustrates the encoded measures of criteria values for the proposed variants and the summation index $J_{i}$ is established according to formula (1). 
Table 4. Encoded measures of criteria values for the proposed variants.

\begin{tabular}{|c|c|c|c|c|}
\hline \multirow{3}{*}{ Criterion } & \multirow{3}{*}{ Weight } & \multicolumn{3}{|c|}{ Encoded measure of the criterion for the variant } \\
\hline & & $V_{1}$ & $\mathbf{V}_{2}$ & $\mathbf{V}_{3}$ \\
\hline & & $\begin{array}{c}\text { Ceramics with } \\
\text { mineral wool }\end{array}$ & $\begin{array}{l}\text { Cellular } \\
\text { concrete }\end{array}$ & $\begin{array}{c}\text { Leca concrete with } \\
\text { styrofoam insert }\end{array}$ \\
\hline $\mathrm{K}_{1}$ coefficient $\mathrm{U}$ & 0.20 & 1.00 & 0.00 & 0.92 \\
\hline $\mathrm{K}_{2}$ execution cost & 0.60 & 0.00 & 1.00 & 0.08 \\
\hline $\mathrm{K}_{3}$ labour intensity & 0.10 & 0.68 & 1.00 & 0.00 \\
\hline $\mathrm{K}_{4}$ sound insulation & 0.10 & 1.00 & 0.00 & 0.67 \\
\hline \multicolumn{2}{|c|}{ Summary indicators $J_{i}$} & 0.37 & 0.70 & 0.30 \\
\hline \multicolumn{2}{|c|}{ Evaluation } & 2 & 1 & 3 \\
\hline
\end{tabular}

The values of the summation index for the considered variants are presented in Figure 2.

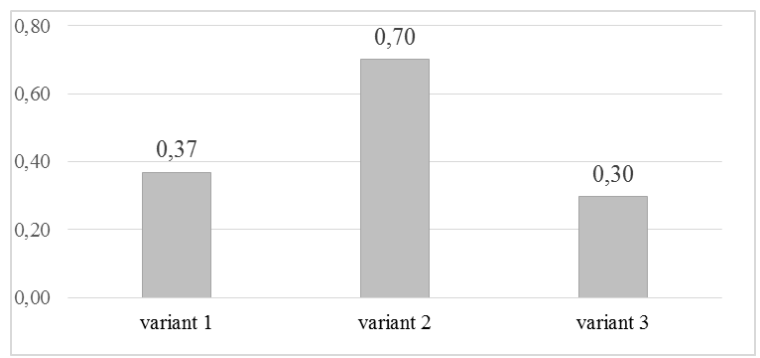

Fig. 2. The values of the summation index for the individual variants.

The multicriteria analysis performed for the adopted criteria and the weights assigned to them revealed that the most advantageous solution is the variant of the wall made of cellular concrete blocks. This result was probably influenced by the decision to accept the price criterion as the criterion with the highest weight. The labour intensity of erecting the partition made of this material is also the smallest. Blocks made of light material can significantly speed up the construction process. When comparing the U coefficient, this material, in comparison to the other two (Table 2), will take the highest value; nevertheless, it still meets the standards currently in force in Poland $(0.23[\mathrm{~W} / \mathrm{m} 2 \mathrm{~K}])$ as well as those that will apply after $2021(0.2[\mathrm{~W} / \mathrm{m} 2 \mathrm{~K}])$.

The difference between the values of the summation index for the other two variants is very small, although it should be noted that with the assumptions made, the second option was the variant involving the ceramic brick filled with mineral wool, in this case the cost of making $1 \mathrm{~m}^{2}$ of the wall of this material was the highest.

\section{Summary}

The paper includes a comparative analysis of three variants of single-layer walls. In order to calculate the costs and determine the labour intensity the authors directly used the following catalogues: KNR K-49 (for variant I), KNR K-28 (for variant II) and KNRW 2-02 that was used by analogy (for variant III).

In order to select the best among the tree variants proposed, the multi-criteria analysis was conducted. Four criteria were adopted to assess the variants discussed: the U coefficient, cost per $1 \mathrm{~m}^{2}$, labour intensity of constructing $1 \mathrm{~m}^{2}$ of the wall, and sound insulation. 
The results obtained revealed that ultimately the best solution is a single-layer wall made of cellular concrete blocks. It should be mentioned that this variant was also the cheapest, even though the weight of the criterion: costs per $1 \mathrm{~m}^{2}$ was the highest. It should be emphasized that the weights of the criteria were accepted by the authors subjectively. Also the method of data coding (the Neumann-Morgenstern method) was accepted a priori. In the case of a change in weight or the data coding method, the evaluation of individual variants may be different.

\section{References}

1. B. Grzyl, E. Miszewska-Urbańska, M. Apollo, E3S Web of Conf., 17, (EDP Sciences 2017)

2. http://wienerberger.pl/informacje/porotherm-dryfix-innowacja-w-murowaniu/

3. http://www.hotblok.pl/index.php/pl/oferta/system-budowy-scian/

4. M. Kaftanowicz, M. Krzeminski, Proc. Eng. 111, doi:10.1016/j.proeng.2015.07.102 (2016)

5. M. Kozlovska, M. Spisakova, D. Mackova, WMCAUS 2017, 245, UNSP 072022 , (2017)

6. A. Leśniak, J. Balicki, EBER, 4, 2 doi: 10.15678/EBER.2016.040206 (2016)

7. A. Leśniak, K. Zima, SGEM 2015 Conf. Proc., 3, 5 (2015)

8. P. Markiewicz, Budownictwo ogólne dla architektów, (Wyd. Archi-Plus, Kraków 2011)

9. E. Moj, M. Śliwiński, Podstawy budownictwa. Część I. Skrypt dla studentów wyższych szkół technicznych do przedmiotu: budownictwo ogóle, (Wyd. PK, Kraków 1998)

10. B. Nowogońska, Engineering Mechanics. 20th international conference, May 12-15, 2014, Svratka, Czech Republic (2014)

11. J. Panas (edit), Budownictwo ogólne. Elementy budynków, podstawy projektowania. Tom 3, (Wyd. Arkady, Warszawa 2008)

12. J. Panas (edit), Budownictwo ogólne. Konstrukcje budynków, Tom 4, (Wyd. Arkady, Warszawa, 2010)

13. E. Plebankiewicz, K. Zima, D. Wieczorek, Arch. Civ. Eng. 62, 2 (2016)

14. Poradnik murowania Ytong, (Xella Polska, Warszawa, 2017)

15. J. Szwabowski, J. Deszcz, Metody wielokryterialnej analizy porównawczej, (Wyd. PŚl, Gliwice, 2001)

16. T. Trzaskalik, Wielokryterialne wspomaganie decyzji. przeglad metod i zastosowań, Zesz. Nauk. Org. Zarz. P. Śl. 74 (2014) 